\title{
Персоналізація лікування хвороби Грейвса на підставі клініко-імунологічних клініко-імунологічних характеристик перебігу захворювання
}

Ю.В. Булдигіна', С.Л. Шляхтич ${ }^{2}$, Г.М. Терехова', Т.В. Федько ', В.М. Клочкова', Л.С. Страфун', 3.Г. Лисова', I.I. Савосько

'ДУ «Інститут ендокринології та обміну речовин ім. В.П. Комісаренка НАМН України»

${ }^{2}$ Київський міський центр ендокринної хірургії КНП «Київська міська клінічна лікарня № 3»

Резюме. Мета - удосконалення алгоритму лікування хвороби Грейвса (ХГ) на основі клініко-імунологічних особливостей перебігу захворювання. У дослідженні взяли участь 346 хворих на тиреотоксикоз. Вивчено показники 310 хворих на ХГ (272 жінки і 38 чоловіків), які були розподілені на дві групи: одну групу становили 126 осіб із ХГ і автоімунною офтальмопатією (АО), другу групу - 184 особи з ХГ без АО. Як контроль використали показники 36 хворих на токсичну аденому (ТА) жіночої статі аналогічного віку. Вікхворих коливався від 18 до

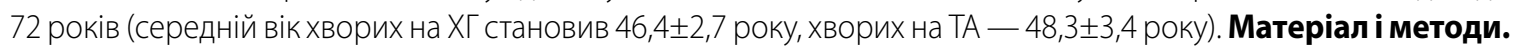
Визначення тиреотропного гормону (ТТГ), вільного тироксину (ВТ $)_{4}$, вільного трийодтироніну $\left(\right.$ ВТ $\left._{3}\right)$ та антитіл до рецепторів тиреотропного гормону (АТ рТТГ) здійснювали методом хемілюмінесцентного імуноаналізу. Діагноз «автоімунна офтальмопатія» виставлено за даними клінічної картини, УзД орбіт, екзофтальмометрії та висновку лікаря-офтальмолога. Статистичний аналіз отриманих результатів здійснювали за методом варіаційної

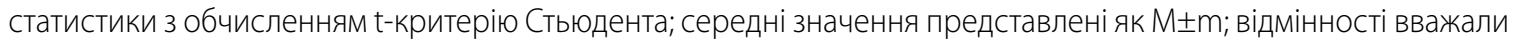
вірогідними за р <0,05. Результати. У хворих на ХГ рівні АТ рТТГ до початку лікування були очікувано вищими за показники хворих на ТА (контрольна група), вірогідно (p<0,05) знижувались тільки через 6 міс. після початку антитиреоїдної терапії, і ця тенденція зберігалась через 12 місяців. У хворих на ТА очікувано не спостерігалося збільшення рівнів АТ рТТГ. У хворих із рецидивами тиреотоксикозу при антитиреоїдній терапії рівні АТ рТТГ

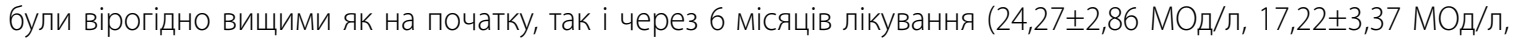

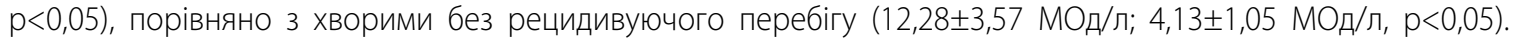
У хворих із ремісією захворювання рівень АТ рТТГ через 6 міс. після терапії досягав мінімальних рівнів 4,13 1,05 МОд/л, але при цьому перевищував референтні лабораторні значення (1,75 МОд/л), що не впливало на стійкість ремісії ХГ. Висновки. 1. Загальноприйняте медикаментозне лікування ХГ необхідно доповнити обов'язковим моніторингом АТ рТТГ через 6 та 12 міс. після початку тиреостатичної терапії. 2. Оскільки вірогідне зниження рівня АТ рТТГ відбувається тільки через 6 місяців після початку терапії, його контроль у більш ранні строки $є$ неінформативним і, відповідно, недоцільним. 3. Через 12 місяців після лікування можна

( Ю.В. Булдигіна, С.Л. Шляхтич, Г.М. Терехова, Т.В. Федько, В.М. Клочкова,

Л.С. Страфун, 3.Г. Лисова, І.І. Савосько 
Діагностика та лікування

спрогнозувати подальший перебіг захворювання на основі значень АТ рТТГ: рівень АТ рTTГ $\leq 4,13$ МОд/л може свідчити про імунологічну ремісію ХГ, а рівень АТ рТТГ $\geq 17$ МОд/л після довготривалої антитиреоїдної терапії $\epsilon$ предиктором розвитку рецидиву захворювання і, у такому випадку, доцільно проводити радикальне лікування хворих (хірургічне втручання чи радіойодтерапію).

Ключові слова: хвороба Грейвса, тиреотоксикоз, антитіла до рецептора тиреотропного гормону, персоналізація, лікування.

Хвороба Грейвса (хвороба Базедова, дифузний токсичний зоб) - органоспецифічне автоімунне захворювання, що розвивається внаслідок вироблення АТ-рТТГ (імуноглобуліну G), клінічно проявляється ураженням щитоподібної залози (ЩЗ) з розвитком синдрому тиреотоксикозу в поєднанні з екстратиреоїдною патологією (ендокринною офтальмопатією, претибіальною мікседемою, акропатією, ураженням серцево-судинної системи, що супроводжується тахікардією та іншими проявами) [1-6]. Автоімунні захворювання ЩЗ (АЗЩЗ) посідають друге місце в структурі ендокринної патології зі сталою тенденцією до зростання, що є показом техногенного забруднення довкілля, і зустрічаються в 7-9\% жінок та 1-2\% чоловіків у різних популяціях [7-10]. Дуже висока частота ХГ спостерігається в період пубертату (майже у 25\% підлітків віком 10-15 років) [11]. Частота нових випадків ХГ у різних державах коливається від 5-7 до 30200 на 100000 населення за рік залежно від йодного забезпечення [12].

Хоча ХГ може спостерігатися в будь-якому віці та в осіб обох статей, це захворювання частіше уражає жінок (майже $3 \%$ проти $0,5 \%$ серед чоловіків), що пов'язано з генетичними чинниками. За даними різних авторів жінки хворіють у 5-20 разів частіше, ніж чоловіки. Пік захворюваності відзначається у віці від 20 до 40 років, тобто, переважно, у людей працездатного віку та призводить до інвалідності хворих [3, 12-15].

Останніми десятиліттями відбувається поглиблене вивчення етіології та патогенезу ХГ. Наразі вже доведено, що ця патологія є класичним автоімунним захворюванням, за якого синтез антитіл до ТТГ та їхнє зв'язування з $\alpha$-субодиницею рецептора ТТГ на мембрані тиреоцита призводить до активації аденілатциклази, підвищення рівня внутрішньоклітинної цАМФ, результатом чого є фосфорилювання протеїнкінази А та активація різних транскрипційних чинників. Ці процеси викликають збільшення захвату йоду, посиленого синтезу тиреоїдної пероксидази і тиреоглобуліну та, в кінцевому результаті, до гіперфункції Щ3 [16, 17].

До генетичних чинників ризику розвитку XГ належать комплекси гаплотипів HLA, які є потенціальними предикторами (наприклад, HLA-DRв-Arg74, HLA-B8, HLA DRB1*3, DQA1*5, DQB1*2 у європейців) [18], протеїн-тирозин-фосфатаза нерецепторного типу 22 (PTPN22), антиген 4 цитотоксичних Т-лімфоцитів (CTLA4) [19, 20], CD25 та CD40, CD80, CD86 [21], фактор виживання В клітин (BAFF) [22], Fas-ліганд (CD95 і CD3г), функції клітин T reg (FoxP3) [4, 23, 24], поліморфізми генів, що кодують пептиди ЩЗ (варіанти тиреоглобуліну або рТТГ) [25, 26], поліморфізм $B A F F$ промоторного регіону rs4000607 вірогідний зв'язок із ХГ у когорті хворих Великої Британії [3, 4, 27, 28].

Є дані про локуси схильності в 14, 18, 20 хромосомах, а також спадковості зчепленої з X-хромосомою $[29,30]$. Yaqin Tu та співавт. наголошують, що тільки однонуклеотидний поліморфізм промоторного регіону rs1800629 гена фактора некрозу пухлин-альфа корелює з підвищеним ризиком розвитку ХГ, особливо серед європейської популяції [31].

Про генетичну схильність до цього захворювання свідчить той факт, що приблизно в 15\% хворих є родичі з цією ж хворобою $[32,33]$. Результати генетичних досліджень, зокрема монозиготних і дизиготних близнюків, свідчать, що генетична схильність відіграє важливу роль у розвитку ХГ $[34,35]$. Деякі автори дотримуються теорії поліпшеного типу успадкування схильності до ХГ.

Особлива роль у патогенезі ХГ належить порушенням регуляції імунної відповіді, а також 
дисбалансу при активації різних субпопуляцій T-хелперів: Th-1, Th-2 і Th-17 [36]. Доведено, що Th22-клітини, які експресують і секретують інтерлейкін-22, беруть участь в імунопатогенезі різних АЗЩЗ, зокрема ХГ [37]. Підвищений рівень патогенних Th17-лімфоцитів i Th22-клітин при автоімунних тиреоїдних порушеннях припускають їхню участь у патогенезі ХГ [38].

У розвитку захворювання беруть участь різні медіатори імунних реакцій: інтерлейкіни, хемокіни та фактори росту [39]. При оцінці вмісту деяких цитокінів (фактора некрозу пухлин-альфа, інтерлейкінів 6 і 8, інтерферону- $\gamma$ ), a також A2-макроглобуліну i лактоферину в крові хворих на ХГ на стадії декомпенсації та після лікування, було виявлено підвищення вмісту в крові інтерлейкінів 6 і 8, лактоферину i A2-макроглобуліну при первинно виявленій або рецидивуючій ХГ і зниження їхнього рівня при лікуванні, що підтверджує участь імунорегуляторних білків у патогенезі захворювання $[40,41]$.

Отримано переконливі дані, які свідчать про вірогідне підвищення рівня інтерферону- $\gamma$ в сироватці крові хворих на ХГ, і кореляція показників інтерферону- $\gamma$ з тяжкістю перебігу захворювання та рівнем $\mathrm{T}_{3}$ i $\mathrm{T}_{4}$ підтверджує важливу патогенетичну роль інтерферону- $\gamma$ при ХГ [42, 43].

Обговорюється також роль про- і протизапальних цитокінів, таких як інтерлейкіни 2, 4, 8 і 10, а також фактора некрозу пухлин-альфа в патогенезі ХГ $[8,44]$. Інші автори також виявили підвищення рівня інтерлейкіну 8 у хворих на ДТЗ з активною ендокринною офтальмопатією порівняно з групою контролю [41]. У дослідженнях останніх років було виявлено взаємозв'язок поліморфізму гена фактора некрозу пухлин альфа і ДТЗ. Так, J.H. Jung та співавт. надали результати метааналізу 10 досліджень, в яких показали взаємозв'язок поліморфізму гена інтерлейкіну 10 і схильністю до АЗЩЗ, зокрема ХГ [45]. D. Elvira та співавт. відзначили підвищений рівень інтерлейкіну 17 і трансформуючого фактора росту- $\beta$ у сироватці хворих на ХГ, що є свідченням певної ролі цих цитокінів у патогенезі автоімунного захворювання [42].

Попри значні досягнення у вивченні патогенезу та ролі імунних механізмів у розвитку
ХГ, залишається багато дискусійних питань щодо тактики лікування цієї хвороби, а саме ролі «імунологічної ремісії» та її відсутності в плануванні як медикаментозного, так і хірургічного лікування. Так, досі незрозуміло, за яких значень АТ ТТГ ми можемо говорити про імунологічну ремісію, а які є предикторами рецидиву ХГ.

Метою дослідження було удосконалення алгоритму лікування хвороби Грейвса на основі клініко-імунологічних особливостей перебігу захворювання.

\section{Матеріал і методи}

Згідно з поставленою метою, проаналізовано об’єм ЩЗ за допомогою ультразвукового дослідження, визначено рівні ТТГ, $\mathrm{BT}_{4}, \mathrm{BT}_{3}$ і АТ pТТГ у хворих на ХГ при первинному встановленні/підтвердженні діагнозу, а також через 3 , 6 і 12 місяців безперервної терапії тиреостатичними препаратами.

У дослідженні взяли участь 346 осіб: 310 хворих на ХГ і 36 хворих на ТА на тлі багатовузлового зоба. Визначення ТТГ, $\mathrm{BT}_{4}, \mathrm{BT}_{3}$ і АТ рТТГ здійснювали методом хемілюмінесцентного імуноаналізу на аналізаторі «Cobase 411» («Roshe Diagnostics GmbH», Німеччина). Референтні значення для ТТГ становили 0,27-4,20 мкОд/мл, для $\mathrm{BT}_{4}-0,93-1,71$ нг/дл, для $\mathrm{BT}_{3}-2,02-4,43$ пг/мл, для АТ рТТГ $>1,75$ МОд/л (для позитивного результату) і <1,75 МОд/л (для негативного результату). Ультразвукове дослідження ЩЗ проводили за допомогою апаратів «Toshiba» SSA-580A та «Ultima» РА ГРИС. 941217.01343 ИЗ.

Діагноз «автоімунна офтальмопатія» виставлено за даними клінічної картини, ультразвукового дослідження орбіт, екзофтальмометрії та висновок лікаря-офтальмолога.

Статистичний аналіз отриманих результатів проводили за методом варіаційної статистики 3 обчисленням t-критерію Стьюдента. Середні значення представлені, як $\mathrm{M} \pm \mathrm{m}$. Відмінності вважали вірогідними за $\mathrm{p}<0,05$.

Дослідження проведено відповідно до етичних стандартів комітету ДУ «Інститут ендокринології та обміну речовин ім. В.П. Комісаренка НАМН України», основних положень «Конвенції про захист прав і гідності людини щодо застосування біології та медицини: 
Діагностика та лікування

Конвенції про права людини та біомедицину», прийнятої Радою Свропи 04.04.1997 р., належної клінічної практики (Good Clinical Practice, GCP) від 1996 р., Гельсінської декларації Всесвітньої медичної асоціації «Етичні принципи медичних досліджень за участю людини в якості об'єкта дослідження», прийнятої в червні 1964 року та переглянутої з 1975 по 2008 рр., і наказу Міністерства охорони здоров'я України «Про затвердження Порядку проведення клінічних випробувань лікарських засобів та експертизи матеріалів клінічних випробувань і Типового положення про комісію 3 питань етики» № 66 від 13.02.2006 р. зі змінами за 2006-2008 pp.

\section{Результати та обговорення}

Проаналізовано показники 310 хворих на ХГ (272 жінки та 38 чоловіків), які були розподілені на дві групи: одну групу становили 126 осіб із ХГ і автоімунною офтальмопатією (АО), другу групу - 184 особи з ХГ без АО. Як контроль використали показники 36 хворих на ТА аналогічного віку і статі, оскільки за цієї патології не розвивається автоімунний процес і рівні антитиреоїдних антитіл, зазвичай, не змінені.

Клінічні характеристики хворих (основна і контрольна група), а також результати лабораторних досліджень на момент встановлення діагнозу наведено в табл. 1.

У процесі дослідження проаналізовано рівні АТ рТТГ в обох групах до початку та через 3, 6 і 12 місяців безперервної антитиреоїдної терапії метимазолом. При дослідженні титрів АТ рТТГ до лікування виявлено значне їх підвищення у хворих на ХГ порівняно з групою

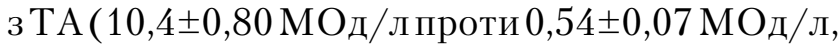
$\mathrm{p}<0,05)$, а різниці в цьому показнику у хворих на АO та без неї не було відмічено (табл. 2).

Через три місяці у всіх 346 хворих зафіксовано стан еутиреозу в результаті медикаментозної компенсації тиреотоксикозу. Рівень ТТГ у загальній групі хворих на ХГ становив

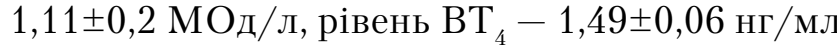
і рівень $\mathrm{BT}_{3}-2,99 \pm 0,31$ пг/мл. У групі хворих на ТА рівень ТТГ склав 0,69 $\pm 0,01 \mathrm{MOд/л,}$ рівень $\mathrm{BT}_{4}-1,99 \pm 0,02$ нг/мл і рівень $\mathrm{BT}_{3}-3,18 \pm 0,43$ пг/мл.
Таблиця 1. Клінічні і лабораторні характеристики груп хворих

Table 1. Clinical and laboratory characteristics of patients groups

\begin{tabular}{|c|c|c|}
\hline $\begin{array}{l}\text { Показник } \\
\text { Indicators }\end{array}$ & $\begin{array}{l}\text { Хворі на ХГ } \\
\text { Patients } \\
\text { with GD } \\
(n=310)\end{array}$ & $\begin{array}{l}\text { Хворі на TA } \\
\text { Patients } \\
\text { with TA } \\
(n=36)\end{array}$ \\
\hline $\begin{array}{l}\text { Biк (роки) } \\
\text { Age, years }\end{array}$ & $46,4 \pm 2,70$ & $48,3 \pm 3,41$ \\
\hline $\begin{array}{l}\text { Кількість жінок/чоловіків } \\
\text { Number of woman/man }\end{array}$ & $272 / 38$ & $36 / 0$ \\
\hline $\begin{array}{l}\text { Тривалість захворювання (роки) } \\
\text { Duration of the disease, years }\end{array}$ & $3,62 \pm 1,12$ & $2,60 \pm 0,90$ \\
\hline $\begin{array}{l}\text { Кількість хворих на АО } \\
\text { Number of patients with } \\
\text { autoimmune ophthalmopathy }\end{array}$ & 126 & 0 \\
\hline $\begin{array}{l}\text { Розміри ЩЗ по Brunn } \\
\text { The size of the thyroid gland by } \\
\text { Brunn }\end{array}$ & $42,10 \pm 6,20$ & $39,94 \pm 4,81$ \\
\hline $\begin{array}{l}\text { ТТГ (мкОд/мл) } \\
\mathrm{TSH}, \mu \mathrm{U} / \mathrm{mL}\end{array}$ & $0,12 \pm 0,01$ & $0,012 \pm 0,005$ \\
\hline $\begin{array}{l}\text { Вільний } T_{4} \text { (нг/дл) } \\
\text { Free } T_{4^{\prime}}, \mathrm{ng} / \mathrm{dL}\end{array}$ & $3,99 \pm 0,16$ & $5,14 \pm 1,02$ \\
\hline 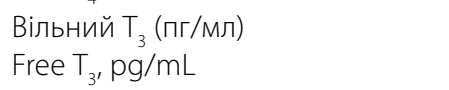 & $6,18 \pm 0,04$ & $7,12 \pm 1,88$ \\
\hline $\begin{array}{l}\text { AT pТTГ (МОд/л) } \\
\text { TSH-R-Abs, IU/L }\end{array}$ & $10,41 \pm 0,80$ & $0,54 \pm 0,07$ \\
\hline
\end{tabular}

Таблиця 2. Порівняльна оцінка рівнів АТ рТТГ у хворих наДТЗ та ТА до лікування

Table 2. Comparative assessment of TSH-R-Abs levels in patients DTG and TA before treatment

\begin{tabular}{|c|c|}
\hline $\begin{array}{l}\text { Групи хворих } \\
\text { Groups of patients }\end{array}$ & $\begin{array}{l}\text { AT рТTГ (МОд/л) } \\
\text { TSH-R-Abs, IU/L }\end{array}$ \\
\hline $\begin{array}{l}\text { Хворі на ХГ } \\
\text { Patients with GD }\end{array}$ & $10,41 \pm 0,8(310)^{*}$ \\
\hline $\begin{array}{l}\text { Хворі на ХГ+AO } \\
\text { Patients with GD+AO }\end{array}$ & $11,07 \pm 1,03(126)^{*}$ \\
\hline $\begin{array}{l}\text { Хворі на ХГ без } \mathrm{AO} \\
\text { Patients with GD without } A O\end{array}$ & $9,29 \pm 1,27(184)^{*}$ \\
\hline $\begin{array}{l}\text { Хворі на TA } \\
\text { Patients with TA }\end{array}$ & $0,54 \pm 0,07(36)$ \\
\hline
\end{tabular}

Примітка: * - вірогідна різниця порівняно з хворими на ТА $(p<0,05)$. Note: ${ }^{*}$ - significant difference compared patients with TA $(p<0.05)$.

При дослідженні рівнів АТ рТТГ у хворих на ХГ протягом тиреостатичної терапії виявлено, що в групі хворих на ХГ і АО, а також із ХГ без $\mathrm{AO}$, титри АТ рТТГ залишались незмінними при контролі через 3 міс. від початку лікування; їх вірогідне зниження ( $<0,05)$ зафіксовано лише через 6 міс. від початку тиреостатичної терапії і ця тенденція зберігалась впродовж наступних 6 міс. (табл. 3 ). 
Таблиця 3. Рівні АТ рТТГ при медикаментозному лікуванні ХГ Table 3. Levels of TSH-R-Abs in the medical treatment of GD

\begin{tabular}{|c|c|c|c|c|}
\hline \multirow{2}{*}{$\begin{array}{l}\text { Групи } \\
\text { хворих } \\
\text { Groups of } \\
\text { patients }\end{array}$} & \multicolumn{4}{|c|}{$\begin{array}{l}\text { АT рТТГ, МОд/л } \\
\text { TSH-R-Abs, IU/L }\end{array}$} \\
\hline & $\begin{array}{l}\text { до } \\
\text { лікування } \\
\text { before } \\
\text { treatment }\end{array}$ & $\begin{array}{l}3 \text { місяці } \\
3 \text { months }\end{array}$ & $\begin{array}{l}6 \text { місяців } \\
6 \text { months }\end{array}$ & $\begin{array}{l}12 \text { місяців } \\
12 \text { months }\end{array}$ \\
\hline $\begin{array}{l}\text { Хворі на } \\
\text { ХГ+AO } \\
\text { Patients } \\
\text { with } \\
\text { GD+AO }\end{array}$ & $11,07 \pm 1,03$ & $9,94 \pm 0,98$ & $5,66 \pm 0,21^{*}$ & $4,64 \pm 1,13^{*}$ \\
\hline $\begin{array}{l}\text { Хворі на ХГ } \\
\text { без AO } \\
\text { Patients } \\
\text { with GD } \\
\text { without AO }\end{array}$ & $9,29 \pm 1,27$ & $8,56 \pm 0,78$ & $4,89 \pm 0,53^{*}$ & $5,01 \pm 0,92^{*}$ \\
\hline
\end{tabular}

Таким чином, рівні АТ рТТГ перед початком антитиреоїдної терапії були очікувано вищими у хворих на ХГ порівняно з показниками контрольної групи з ТА. Їх вірогідне $(\mathrm{p}<0,05)$ зниження зафіксовано тільки через 6 міс. після початку антитиреоїдної терапії й ця тенденція зберігалась при контролі через 12 міс. У хворих на ТА збільшення рівнів АТ рТТГ очікувано не спостерігалося.

Серед усіх 310 хворих на ХГ, що лікувались антитиреоїдними препаратами більше одного року, стійка ремісія тиреотоксикозу (відсутність клінічної симптоматики та еутиреоїдний стан протягом 6 міс. після закінчення лікування чи приймання підтримуючих доз 5 мг метимазолу щодня) була досягнута в 139 хворих (44,84\%), а в 171 хворого (55,16\%) спостерігались рецидиви захворювання при плановому зменшенні дози антитиреоїдних препаратів. Аналіз чинників виникнення рецидиву ХГ здійснювався 3 урахуванням розмірів зоба та АТ рТТГ.

При порівняльному аналізі об'єму Щ3 та титрів АТ рТТГ у хворих із ремісією та рецидивами тиреотоксикозу при ХГ, отримані результати, які свідчать, що у хворих із рецидивуючим перебігом захворювання були вірогідно більшими розміри зоба (об'єм ЩЗ) та рівні АТ рТТГ як на початку лікування, так і при контролі через 6 міс. У цей же термін титри АТ рТТГ знижувалися як у хворих таблиця 4. Порівняльна оцінка результатів медикаментозного лікування у хворих із ремісією та рецидивами ДТЗ до початку і через 6 місяців лікування Table 4. Comparative evaluation of the results of medical treatment in patients with remission and recurrence of DTG before and after 6 months of treatment

\begin{tabular}{|c|c|c|c|c|}
\hline \multirow[t]{2}{*}{$\begin{array}{l}\text { Групи } \\
\text { Groups }\end{array}$} & \multirow[t]{2}{*}{$\begin{array}{l}\text { Вік (роки) } \\
\text { Age, years }\end{array}$} & \multirow{2}{*}{$\begin{array}{l}\text { Об'єм щ3 } \\
\left(\mathrm{cm}^{3}\right) \\
\text { Volume } \\
\text { of thyroid } \\
\text { gland, } \mathrm{cm}^{3}\end{array}$} & \multicolumn{2}{|c|}{$\begin{array}{l}\text { АT рТTГ, МОд/л } \\
\text { TSH-R-Abs, IU/L }\end{array}$} \\
\hline & & & $\begin{array}{l}\text { до } \\
\text { лікування } \\
\text { before } \\
\text { treatment }\end{array}$ & $\begin{array}{l}\text { після } \\
\text { лікування } \\
\text { after } \\
\text { treatment }\end{array}$ \\
\hline $\begin{array}{l}\text { Ремісія } \\
\text { Remission } \\
(n=24)\end{array}$ & $40,66 \pm 2,84$ & $22,02 \pm 1,98$ & $12,28 \pm 3,57$ & $4,13 \pm 1,05$ \\
\hline $\begin{array}{l}\text { Рецидив } \\
\text { Relapse } \\
(n=42)\end{array}$ & $43,37 \pm 2,24^{*}$ & $39,27 \pm 4,63^{*}$ & $24,27 \pm 2,86^{*}$ & $17,22 \pm 3,37^{*}$ \\
\hline
\end{tabular}

Примітка: * - вірогідна різниия між групами $(p<0,05)$.

Note: ${ }^{*}$ - significant difference between groups $(p<0.05)$.

із ремісією, так і у хворих із рецидивуючим перебігом захворювання, проте в групі хворих із рецидивами титри АТ рТТГ вірогідно перевищували значення групи 3 ремісією ХГ

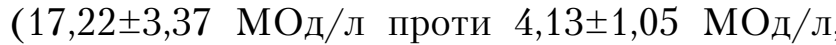
$\mathrm{p}<0,05)$ (табл. 4).

При порівнянні показників хворих зі стійкою ремісією і частими рецидивами тиреотоксикозу при ХГ отримано наступні результати: у хворих iз рецидивуючим перебігом захворювання спостерігались вірогідно більші розміри зоба (об'єм ЩЗ), ніж у групі хворих зі стійкою ремісією $\left(39,27 \pm 4,63 \mathrm{~cm}^{3}\right.$ проти $22,02 \pm 1,98 \mathrm{~cm}^{3}$, $\mathrm{p}<0,05)$. Рівні АТ рТТГ у хворих із рецидивами також вірогідно $(\mathrm{p}<0,05)$ перевищували рівень аналогічних антитіл у хворих із ремісією захворювання. Через 6 міс. після початку лікування титри АТ рТТГ знижувалися як у хворих із ремісією, так і у хворих із рецидивним перебігом захворювання, проте у хворих із рецидивами рівні АТ рТТГ значно перевищували рівні у хворих із ремісією ХГ $(17,22 \pm 3,37$ МОд/л проти

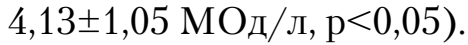

$\mathrm{У}$ подальшому хворі на ТА і ХГ, які мали об'єм ЩЗ >40 см ${ }^{3}$ та ускладнення тиреотоксикозу («тиреотоксичне серце» 3 фібриляцією передсердь та AO), а також рецидивний перебіг тиреотоксикозу, були направлені на хірургічне лікування.

Таким чином, можна відзначити, що титри АТ рТТГ у хворих на ХГ були очікувано підвищені як у хворих зі стійкою ремісією, 
Діагностика та лікування

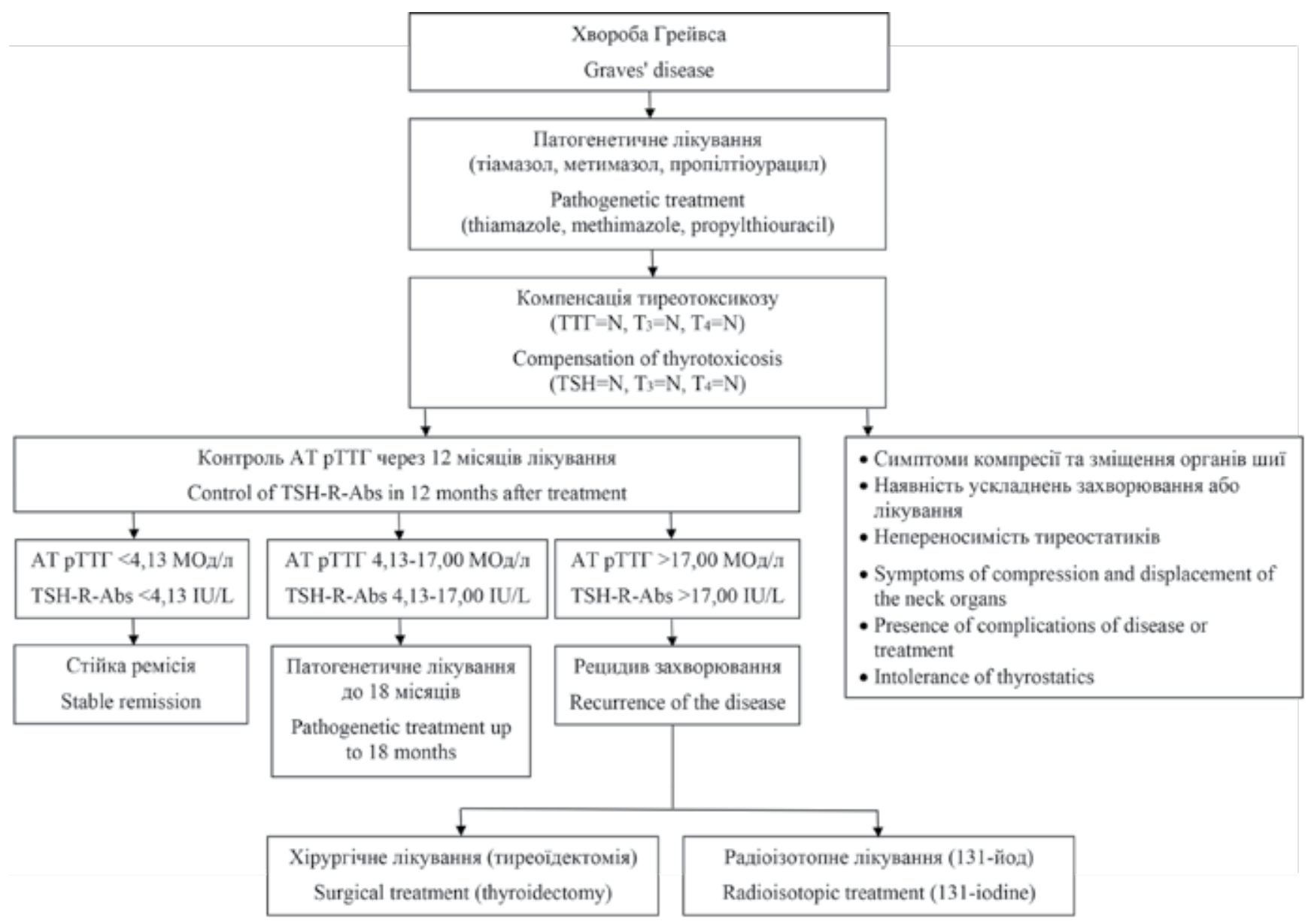

Рис. Алгоритм лікування хвороби Грейвса на підставі клініко-імунологічних характеристик

Fig. Algorithm of Graves' disease treatment on the basis of clinical and immunological characteristics

так і при рецидивному перебігу ХГ. При 6-місячному лікуванні тиреостатиками рівні АТ рТТГ у хворих із рецидивним перебігом ХГ не

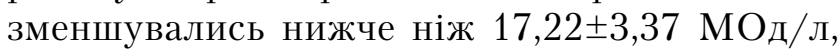
що значно перевищувало аналогічний показник групи 3 ремісією ХГ. Таким чином, великі розміри зоба, високий рівень АТ рТТГ і відсутність його суттєвого зменшення при лікуванні антитиреоїдними препаратами, є предикторами рецидиву тиреотоксикозу за ХГ та обумовлюють необхідність радикального лікування (рис.).

Узагальнюючи результати дослідження, можна стверджувати, що перший контроль рівня АТ рТТГ за ХГ доцільно здійснювати не раніше, ніж через 6 місяців після початку лікування антитиреоїдними препаратами. Виходячи 3 того, що через 12 міс. антитиреоїдної терапії припиняється подальше зменшення рівнів АТ рТТГ, то в цей термін є можливість спрогнозувати перебіг захворювання. Результати вивчення рівнів АТ рТТГ у хворих із рецидивами захворювання при антитиреоїдній терапії засвідчили, що у хворих із рецидивами тиреотоксикозу рівні АТ рТТГ були вірогідно вищими як на початку лікування, так і при контролі через 6 місяців $(24,27 \pm 2,86$ МОд/л; 17,22 $\pm 3,37$ МОд/л, $\mathrm{p}<0,05)$, порівняно з хворими без рецидивного

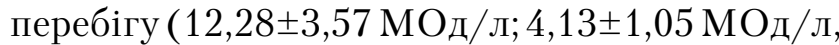
$\mathrm{p}<0,05)$.

Таким чином, титри АТ рТТГ знижувалися через 6 місяців після початку лікування як у хворих зі стійкою ремісією, так і у хворих iз рецидивуючим перебігом захворювання, однак у хворих із рецидивами тиреотоксикозу рівні АТ рТТГ значно перевищували нормальні значення як на початку, так і після 6 міс. медикаментозного лікування. У хворих із ремісією захворювання рівень АТ рТТГ через 6 міс. терапії досягав міні-

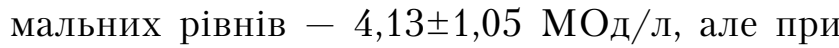


цьому перевищував референтні лабораторні значення (1,75 МОд/л), що не впливало на стійкість ремісії ХГ.

Рівень загальних АТ рТТГ, вищий ніж 17 МОд/л через 12 міс. медикаментозного лікування ДТЗ, є предиктором рецидивування хвороби i вказує на безперспективність подальшої антитиреоїдної терапії. Концентрація загальних АТ рТТГ на рівні 4,13 МОд/л, незважаючи на референтні лабораторні значення, може вважатись показником імунологічної ремісії ХГ та потребує подальшого клінічного спостереження за хворими. Отримані результати дослідження дозволили розробити персоналізований алгоритм лікування ХГ, наведений на рисунку.

\section{Висновки}

1. Загальноприйняте медикаментозне лікування ХГ необхідно доповнити обов'язковим моніторингом АТ рТТГ через 6 та 12 міс. після початку тиреостатичної терапії.

2. Оскільки вірогідне зниження АТ рТТГ відбувається тільки через 6 міс. після початку терапії, контроль у більш ранні строки є неінформативним i, відповідно, недоцільним.

3. Через 12 міс. після початку терапії можливо спрогнозувати подальший перебіг захворювання на основі значень АТ рТТГ: концентрація АТ рТТГ $\leq 4,13$ МОд/л може свідчити про імунологічну ремісію ХГ, а значення АТ рТТГ $\geq 17$ МОд/л є предиктором розвитку рецидиву захворювання, що робить доцільним радикальне лікування цих хворих (хірургічне чи радіойодтерапію).

\section{Список використаної літератури}

1. Савченко АА, Догадин СА, Дудина МА, Мацынина ВП. Клинико-иммунологические показатели и их взаимосвязь с тиреоидным статусом у больных болезнью Грейвса в зависимости от уровня аутоантител $к$ тиреопероксидазе Проблемы эндокринологии. 2016;62(1):4-9. doi: 10.14341/ probl20166214-9 (Savchenko AA, Dogadin SA, Dudina MA Matsynina VP. Clinical and immunological parameters and their relationship with thyroid status in patients with Graves' disease, depending on the level of autoantibodies to thyroperoxidase. Problemy endokrinologii. 2016 Jan;62(1):4-9. doi: 10.14341/ probl20166214-9. Russian).

2. Braverman LE, Utiger RD. The thyroid: a fundamental and clinical text. 9th edition. J.B. Lippicott Co., Phylodelphia. 2005:474-85.
3. Smith TJ, Hegedüs L. Graves' disease. N Engl J Med. 2016 Oct 375(16):1552-65. doi: 10.1056/NEJMra1510030.

4. Li HN, Li XR, Du YY, Yang ZF, Lv ZT. The association between Foxp3 polymorphisms and risk of Graves' disease: A systematic review and meta-analysis of observational studies. Front Endocrinol (Lausanne). 2020 Jun 16;11:392. doi: 10.3389/ fendo.2020.00392.

5. Davies TF, Andersen S, Latif R, Nagayama Y, Barbesino G, Brito M, et al. Graves' disease. Nat Rev Dis Primers. 2020 Jul;6(1):52. doi 10.1038/s41572-020-0184-y.

6. Kahaly GJ, Olivo PD. Graves' Disease. N Engl J Med. 2017 Jan 12;376(2):184. doi: 10.1056/NEJMc1614624.

7. Miteva MZ, Nonchev BI, Orbetzova MM, Stoencheva SD Vitamin D and autoimmune thyroid diseases - a review. Folia Med (Plovdiv). 2020 Jun 30;62(2):223-9. doi: 10.3897/folmed.62. e47794.

8. Грязнова МА, Хамнуева ЛЮ. Особенности цитокиновой регуляции при аутоиммунной патологии щитовидной железы (обзор). Журнал научных статей здоровье и образование в XXI веке. 2017;19(7):33-9 (Gryaznova MA, Khamnuyeva LYu. Features of cytokine regulation in autoimmune thyroid pathology (review). 2017;19(7):33-9. Russian).

9. Sarfo-Kantanka O, Sarfo FS, Ansah EO, Kyei I. Graves' disease in Central Ghana: clinical characteristics and associated factors. Clin Med Insights Endocrinol Diabetes. 2018 Mar 21;11:1179551418759076. doi: 10.1177/1179551418759076.

10. Wiersinga WM. Clinical relevance of environmental factors in the pathogenesis of autoimmune thyroid disease. Endocrinol Metab (Seoul). 2016 Jun;31(2):213-22. doi: 10.3803/EnM.2016.31.2.213.

11. Фархутдинова ЛМ, Бруй АЛ. Возрастные особенности диффузного токсического зоба. Случай из практики. Архивъ внутренней медицины. 2015;3:40-4 (Farkhutdinova LM, Bruy AL. Age features of diffuse toxic goiter. A case from practice. Arkhiv vnutrenney meditsiny. 2015;3:40-4. Russian).

12. Hussain YS, Hookham JC, Allahabadia A, Balasubramanian SP Epidemiology, management and outcomes of Graves' disease-real life data. Endocrine. 2017 Jun;56(3):568-78. doi: 10.1007/s12020017-1306-5

13. Burch HB, Cooper DS. Management of Graves' disease. A review. JAMA. 2015 Dec15;314(23):2544-54. doi: 10.1001/ jama.2015.16535. Erratum in: JAMA. 2016 Feb 9;315(6):614.

14. Пашенцева АВ, Вербовой АФ. Диффузный токсический зоб. Клиническая медицина. 2017; 9:780-8 (Pashentseva AV Verbovoy AF. Diffuse toxic goiter. Klinicheskaya meditsina. 2017;9:780-8. Russian).

15. Vejrazkova D, Vcelak J, Vaclavikova E, Van Kova M, Zajickova K, Duskova M, et al. Genetic predictors of the development and recurrence of Graves' disease. Physiol Res. 2018 Nov 28;67(Suppl 3): S431-9. doi: 10.33549/physiolres.934018.

16. Rapoport B, Aliesky HA, Chen C-R, McLachlan SM. Evidence that TSH receptor A-subunit multimers, not monomers, drive antibody affinity maturation in Graves' disease. J Clin Endocrinol Metab. 2015 Jun;100(6): E871-5. doi: 10.1210/jc.2015-1528.

17. Bartalena L, Burch HB, Burman KD, Kahaly GJ. A 2013 European survey of clinical practice patterns in the management of Graves' disease. Clin Endocrinol (Oxf). 2016 Jan;84(1):115-20. doi: $10.1111 /$ cen.12688.

18. Jurecka-Lubieniecka B, Bednarczuk T, Ploski R, Krajewska J, Kula D, Kowalska M, et al. Differences in gene-gene interactions in Graves' disease patients stratified by age of onset. PLoS One. 2016 Mar 4;11(3): e0150307. doi: 10.1371/journal.pone.0150307.

19. Pawlak-Adamska E, Frydecka I, Bolanowski M, Tomkiewicz A, Jonkisz A, Karabon L, et al. CD28/CTLA-4/ICOS haplotypes confers susceptibility to Graves' disease and modulates clinical phenotype of disease. Endocrine. 2017 Jan;55(1):186-99. doi: 10.1007/ s12020-016-1096-1.

20. Eliana F, Suwondo P, Asmarinah A, Harahap A, Djauzi S, Prihartono J, et al. The role of cytotoxic T-lymphocyte-associated protein 4 (CTLA-4) gene, thyroid stimulating hormone receptor (TSHR) gene and regulatory T-cells as risk factors for relapse in patients with Graves' disease. Acta Med Indones. 2017 Jul;49(3):195-204.

21. Watanabe $\mathrm{A}$, Inoue $\mathrm{N}$, Watanabe $\mathrm{M}$, Yamanoto $\mathrm{M}$, Ozaki $\mathrm{H}, \mathrm{Hi}-$ daka Y, Iwatani Y. Increases of CD80 and CD86 expression on peripheral blood cells and their gene polymorphisms in autoimmune 
Діагностика та лікування

thyroid disease. Immunol Invest. 2020 Nov;49(1-2):191-203. doi: 10.1080/08820139.2019.1688343.

22. Lane LC, Allinson KR, Campbell K, Bhatnagar I, Ingoe L, Razvi S, et al. Analysis of BAFF gene polymorphisms in UK Graves' disease patients. Clin Endocrinol (Oxf). 2019 Jan;90(1):170-4. doi: 10.1111/cen.13872.

23. Pawlowski P, Grubczak K, Kostecki J, Ilendo-Poskrobko E, Moniuszko M, Pawlowska M, et al. Decreased frequencies of peripheral blood CD4+CD25+CD127-Foxp3+ in patients with Graves' disease and Graves orbitopathy: Enhancing effect of insulin growth factor-1 on Treg cells. Horm Metab Res. 2017 Mar;49(3):185-91. doi: $10.1055 / \mathrm{s}-0042-122780$.

24. Shehjar F, Afroze D, Misgar RA, Malik SA, Laway BA. Association of FoxP3 promoter polymorphisms with the risk of Graves' disease in ethnic Kashmiri population. Gene. 2018 Sep 25;672:88-92. doi: 10.1016/j.gene.2018.06.023.

25. Fujii $\mathrm{A}$, Inoue $\mathrm{N}$, Watanabe $\mathrm{M}$, Kawakami $\mathrm{C}$, Hidaka $\mathrm{Y}$, Hayashizaki Y, Iwatani Y. TSHR gene polymorphisms in the enhancer regions are most strongly associated with the development of Graves' disease, especially intractable disease, and of Hashimoto's disease. Thyroid. 2017 Jan;27(1):111-9. doi: 10.1089/thy.2016.0345.

26. Pujol-Borrell R, Álvarez-Sierra D, Jaraquemada D, Marín-Sánchez A, Colobran R. Central tolerance mechanisms to TSHR in Graves' disease: Contributions to understand the gene association. Horm Metab Res. 2018 Dec;50(12):863-70. doi: 10.1055/a-0755-7927.

27. Саприна ТВ, Прохоренко ТС, Рязанцева НВ, Ворожцова ИН, Мартынова СЮ, Дзюман АН, и др. Иммунологические и морфологические предикторы клинической гетерогенности пациентов с болезнью Грейвса (по результатам исследования оперативного материала щитовидной железы). Бюллетень сибирской медицины. 2015;14(1):81-91 (Saprina TV, Prokhorenko TS, Ryazantseva NV, Vorozhtsova IN, Martynova SYu, Dzyuman AN, et al. Immunological and morphological predictors of clinical heterogeneity in patients with Graves' disease (based on the results of a study of the operative material of the thyroid gland). Byulleten' sibirskoy meditsiny. 2015;14(1):81-91. Russian).

28. Limbach M, Saare M, Tserel L, Kisand K, Eglit T, Sauer S, et al. Epigenetic profiling in $\mathrm{CD} 4+$ and $\mathrm{CD} 8+\mathrm{T}$ cells from Graves' disease patients reveals changes in genes associated with $\mathrm{T}$ cell receptor signaling. J Autoimmun. 2016 Feb;67:46-56. doi: 10.1016/j.jaut.2015.09.006.

29. Cho WK, Shin HR, Lee NY, Kim SK, Ahn MB, Baek IC, et al. GPR174 and ITM2A gene polymorphisms rs3827440 and rs5912838 on the $\mathrm{X}$ chromosome in Korean children with autoimmune thyroid disease. Genes (Basel). $2020 \mathrm{Jul} ; 11(8): 858$. doi: $10.3390 /$ genes11080858.

30. Latif R, Mezei M, Morshed SA, Ma R, Ehrlich R, Davies TF. A modifying autoantigen in Graves' disease. Endocrinology. 2019 May 1;160(5):1008-20. doi: 10.1210/en.2018-01048.

31. Tu Y, Fan G, Zeng T, Cai X, Kong W. Association of TNF-a promoter polymorphism and Graves' disease: an updated systematic review and meta-analysis. Biosci Rep. 2018 Mar 21;38(2): BSR20180143. doi: 10.1042/BSR20180143.

32. Thomsen H, Li X, Sundquist K, Sundquist J, Fцrsti A, Hemminki K. Familial risks between Graves' disease and Hashimoto thyroiditis and other autoimmune diseases in the population of Sweden. J Transl Autoimmun. 2020 Jun 1;3:100058. doi: $10.1016 /$ j.jtauto.2020.100058.

33. Рымар ОД, Пьянкова АК, Максимов ВН, Шахматов СГ, Щепина ЮВ, Рябиков АН, Мустафина СВ. Анализ ассоциаций полиморфизма генов-кандидатов аутоиммунных заболеваний у лиц с семейными случаями диффузного токсического зоба и аутоиммунного тиреоидита. Клиническая и экспериментальная тиреоидология. 2016;12(2):46-54 (Rymar OD, P'yankova AK, Maksimov VN, Shakhmatov SG, Shchepina YuV, Ryabikov AN, Mustafina SV. Analysis of associations of polymorphism of candidate genes for autoimmune diseases in individuals with familial cases of diffuse toxic goiter and autoimmune thyroiditis. Klinicheskaya i eksperimental'naya tireoidologiya. 2016;12(2):46-54. Russian).

34. Brix TH, Hegedüs L. Twin studies as a model for exploring the aetiology of autoimmune thyroid disease. Clin Endocrinol (Oxf). 2012 Apr;76(4):457-64. doi: 10.1111/j.1365-2265.2011.04318.x.

35. Балаболкин М, Клебанова Е, Креминская В. Фундаментальная и клиническая тиреоидология (руководство). Москва: Меди- цина. 2007. 816 с. (Balabolkin M, Klebanova Ye, Kreminskaya V. Fundamental and clinical thyroidology (rukovodstvo). Moskva: Meditsina. 2007. 816 p. Russian)

36. Teniente-Serra A, Soldevila B, Quirant-Sánchez B, Fernández MA, Ester Condins A, Puig-Domingo M, et al. Distinct pattern of peripheral lymphocyte subsets in Graves' disease with persistency of anti-TSHR autoantibodies. Autoimmunity. 2019 AugSep;52(5-6):220-7. doi: 10.1080/08916934.2019.1646253.

37. Huang Y, Fang S, Li D, Zhou H, Li B, Fan X. The involvement of T cell pathogenesis in thyroid-associated ophthalmopathy. Eye (Lond). 2019 Feb;33(2):176-82. doi: 10.1038/s41433-018-0279-9.

38. Vitales-Noyola M, Ramos-Levi AM, Martínez-Hernández R, Serrano-Somavilla A, Sampedro-Nuñez M, González-Amaro R, Marazuela M. Pathogenic Th17 and Th22 cells are increased in patients with autoimmune thyroid disorders. Endocrine. 2017 Sep;57(3):409-17. doi: 10.1007/s12020-017-1361-y.

39. Fallahi P, Ferrari SM, Ragusa F, Ruffilli I, Elia G, Paparo SR, et al. Th1 chemokines in autoimmune endocrine disorders. J Clin Endocrinol Metab. 2020 Apr 1;105(4): dgz289. doi: 10.1210/clinem/dgz289.

40. Маклакова ТП, Зорина ВН, Янышева ДВ, Мезенцева ЕВ, Зорин НА. Иммунорегуляторные белки и цитокины в крови пациентов с болезнью Грейвса. Проблемы эндокринологии. 2019; 1:4-9 (Maklakova TP, Zorina VN, Yanysheva DV, Mezentseva YEV, Zorin NA. Immunoregulatory proteins and cytokines in the blood of patients with Graves' disease. Problemy endokrinologii. 2019;1:4-9. Russian). doi: 10.14341/probl9567.

41. Nowak M, Siemicska L, Karpe J, Marek B, Kos-Kudia B, Kajdaniuk D. Serum concentrations of HGF and IL-8 in patients with active Graves' orbitopathy before and after methylprednisolone therapy. $J$ Endocrinol Invest. 2016 Jan;39(1):63-72. doi: 10.1007/s40618-015-0322-7.

42. Elvira D, Nasrul E, Sofyan Y, Decroli E, Darwin E. Increased serum levels of interleukin-17 and transforming growth factor-b in patients with Graves' disease. IOP Conf. Series: Earth and Environmental Science. 2018 March; 125(1):012163. doi: 10.1088/1755-1315/125/1/012163.

43. Здор ВВ, Гельцер БИ. Новые аспекты иммунопатогенеза болезни Грейвса - цитокиновая регуляция и клеточная инфильтрация щитовидной железы при аутоиммунном тиреотоксикозе. Российский иммунологический журнал. 2019;22(2-1):260-3 (Zdor VV, Gel'tser BI. New aspects of the immunopathogenesis of Graves' disease - cytokine regulation and cellular infiltration of the thyroid gland in autoimmune thyrotoxicosis. Rossiyskiy immunologicheskiy zhurnal. 2019;22(2-1):260-3. Russian).

44. Здор ВВ, Маркелова ЕВ, Гельцер БИ. Тиреоидный статус и его взаимосвязь с функциональной активностью иммуноцитов. Медицинская иммунология. 2017; 19(3):293-300 (Zdor VV, Markelova YeV, Gel'tser BI. Thyroid status and its relationship with the functional activity of immunocytes. Meditsinskaya immunologiya. 2017;19(3):293-300. Russian).

45. Jung JH, Song GG, Kim JH, Choi SJ. Association of interleukin 10 gene polymorphisms with autoimmune thyroid disease: metaanalysis. Scand J Immunol. 2016 Nov;84(5):272-7. doi: 10.1111/ sji.12470.

\section{Personalization of Graves' disease treatment on the basis of clinical and immunological characteristics of the disease}

\section{Yu.V. Buldygina', S.L. Shlyakhtych, H.M. Terekhova', T.V. Fed'ko', V.M. Klochkova', L.S. Strafun', Z.H. Lysova', I.I. Savos'ko'}

${ }^{1} \mathrm{SI}$ «V.P. Komissarenko Institute of Endocrinology and Metabolism of National Academy of Medical Sciences of Ukraine»

${ }^{2}$ Kyiv City Center for Endocrine Surgery of Kyiv City Clinical Hospital N3

Abstract. The aim is to improve an algorithm for treating Graves' disease (GD) based on the clinical and immunological features of 
the disease. The study involved 346 patients with thyrotoxicosis. The indicators of 310 patients with GD (272 women and 38 men) were studied. The patients were further divided into two groups: one group consisted of 126 patients with GD and autoimmune ophthalmopathy $(A O)$, the second group - patients with GD without AO (184 people). Indices of 36 patients (36 women) of the same age with toxic adenoma (TA) were used as a control group. The age of patients ranged from 18 to 72 years (mean age of patients with Graves' disease was $46.4 \pm 2.7$ years, with toxic adenoma $-48.3 \pm 3.4$ years). Materials and methods. Determination of TSH, free $T_{4^{\prime}}$ free $T_{3^{\prime}}$ thyrotropin receptor antibodies (TSH-R-Abs) was carried out by using the chemiluminescent immunoassay. The diagnosis of «autoimmune ophthalmopathy» was made according to the clinical picture, ultrasound of the orbits, exophthalmometry, the conclusion of an ophthalmologist. Statistical analysis of the results was performed by the method of variation statistics with the calculation of Student's t-test. The average values are presented as $M \pm m$. Differences were considered significant at $p<0.05$. Results. Summarizing the results of the study for TSH-R-Abs titers during long-term conservative treatment (12 months), we can state that TSH-R-Abs levels in patients with GD before treatment were expected to be higher than in the control group of patients with TA, significantly decreased $(p<0.05)$ in 6 months after the start of antithyroid therapy and this tendency persisted under control for 12 months. No increase in TSH-R-Abs levels was expected in patients with TA. The results of studying the TSH-R-Abs levels in patients with the disease recurrence during antithyroid therapy showed that TSH-R-Abs levels were significantly higher both at the beginning of treatment and at control in 6 months after in patients with recurrent thyrotoxicosis $(24.27 \pm 2.86 \mathrm{IU} / \mathrm{L}$; $17.22 \pm 3.37 \mathrm{IU} / \mathrm{L}, \mathrm{p}<0.05)$, than in patients without recurrent course (12.28 $2.57 \mathrm{IU} / \mathrm{L} ; 4.13 \pm 1.05 \mathrm{IU} / \mathrm{L}, \mathrm{p}<0.05)$. In patients with remission of the disease, as mentioned above, the level of TSH-R-Abs reached minimum levels $-4.13 \pm 1.05 \mathrm{IU} / \mathrm{L}$ in 6 months after therapy, but at the same time exceeded the reference laboratory values $(1.75 \mathrm{IU} / \mathrm{L})$, which did not affect the stability of GD remission.

Conclusions. 1. The generally accepted medical treatment of GD should be supplemented with obligatory monitoring of TSH-R-Abs in 6 and 12 months after the beginning of thyrostatic therapy. 2 . Considering the fact that only in 6 months after the beginning of therapy there is a significant decrease in TSH-R-Abs, their control in earlier terms is uninformative and, therefore, inexpedient, respectively. 3. In 12 months after treatment on the basis of TSH$\mathrm{R}$-Abs values it be possible to predict the further course of the disease: TSH-R-Abs concentration $\leq 4.13 \mathrm{IU} / \mathrm{mL}$ may indicate immunological remission of GD and TSH-R-Abs value $\geq 17 \mathrm{IU} / \mathrm{mL}$ after long-term antithyroid therapy, is a predictor of recurrence and, in this case, it is advisable to carry out radical treatment of patients (surgery or radioiodine therapy).

Keywords: Graves' disease, thyrotoxicosis, thyrotropin receptor antibodies, personalization, treatment.

\section{Персонализация лечения болезни Грейвса на основании клинико-иммунологических характеристик течения заболевания}

\author{
Ю.В. Булдыгина', С.Л. Шляхтич, Г.Н. Терехова', \\ Т.В. Федько, В.Н. Клочкова', Л.С. Страфун', \\ 3.Г. Лысова', И.И. Савосько \\ 'ГУ «Институт эндокринологии и обмена веществ им. \\ В.П. Комиссаренко НАМН Украины» \\ ${ }^{2}$ Киевский городской центр эндокринной хирургии КНП «Киевская \\ городская клиническая больница № 3»
}

Резюме. Цель - усовершенствование алгоритма лечения болезни Грейвса (БГ) на основании клинико-иммунологических особенностей течения заболевания. В исследовании приняли участие 346 больных с тиреотоксикозом. Изучены показатели 310 больных с БГ (272 женщины и 38 мужчин), которые в дальнейшем были разделены на две группы: одну группу составили 126 лиц с БГ и аутоиммунной офтальмопатией (АО), вторую группу — больные с БГ без АО (184 человека). В качестве контроля использовались показатели 36 больных с токсической аденомой (ТА) женского пола аналогичного возраста. Возраст больных колебался от 18 до 72 лет (средний возраст больных с БГ составлял 46,4 2,7 лет, с токсической аденомой - 48,3 33,4 лет). Материал и методы. Определение ТТГ, свободного $T_{4^{\prime}}$ свободного $T_{3^{\prime}}$ АТ рТТГ выполняли с помощью метода хемилюминесцентного иммуноанализа. Диагноз «аутоиммунная офтальмопатия» выставлен по данным клинической картины, Узи орбит, экзофтальмометрии и заключения врача-офтальмолога. Статистический анализ полученных результатов осуществляли по методу вариационной статистики с вычислением t-критерия Стьюдента. Средние значения представлены как $\mathrm{M} \pm \mathrm{m}$. Различия считали вероятными при р<0,05. Результаты. Обобщая результаты исследования титров АТ рТТГ в процессе длительного консервативного лечения в течение 12 месяцев, можно констатировать, что у больных БГ уровни АТ рТТГ до начала лечения были ожидаемо выше показателей контрольной группы больных с ТА, достоверно $(p<0,05)$ снижались через 6 мес. после начала антитиреоидной терапии и эта тенденция сохранялась при контроле через 12 мес. У пациентов с ТА увеличение уровней АТ рТТГ ожидаемо не наблюдалось. Результаты изучения уровней АТ рТТГ у больных с рецидивами заболевания при антитиреоидной терапии показали, что у больных с рецидивами тиреотоксикоза уровни АТ рТТГ были достоверно выше как вначале лечения, так и через 6 мес. после лече-

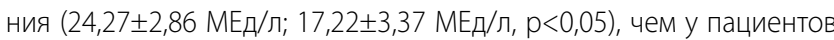

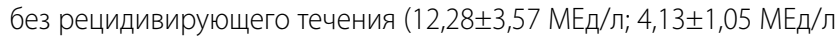
p<0,05). У больных с ремиссией заболевания, как было отмечено выше, уровень АТ рТТГ через 6 мес. после терапии достигал ми-

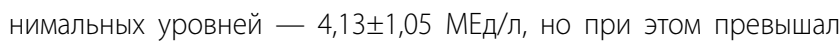
референтные лабораторные значения (1,75 МЕд/л), что не влияло на устойчивость ремиссии БГ.). Выводы. 1. Общепринятое медикаментозное лечение БГ необходимо дополнить обязательным мониторингом АТ рТТГ через 6 и 12 мес. после начала тиреоста- 
Діагностика та лікування

тической терапии. 2. Поскольку достоверное снижение уровня АТ рТТГ происходит только через 6 мес. после начала терапии, то его контроль в более ранние сроки является неинформативным и, соответственно, нецелесообразным. 3. Через 12 мес. после лечения на основании значений АТ рТТГ возможно спрогнозировать дальнейшее течение заболевания: уровень АТ рТТГ $\leq 4,13$ МЕд/мл может свидетельствовать об иммунологической ремиссии БГ, а уровень АТ рТТГ $\geq 17$ МЕд/мл после длительной антитиреоидной терапии, является предиктором развития рецидива заболевания и, в таком случае, целесообразно проводить радикальное лечение больных (хирургическое вмешательство или радиойодтерапию).

Ключевые слова: болезнь Грейвса, тиреотоксикоз, антитела к рецептору тиреотропного гормона, персонализация, лечение.

Для цитування: Булдигіна ЮВ, Шляхтич СЛ, Терехова ГМ, Федько ТВ, Клочкова ВМ, Страфун ЛС, Лисова ЗГ, Савосько II. Персоналізація лікування хвороби Грейвса на підставі клініко-імунологічних характеристик перебігу захворювання. Ендокринологія. 2021;26(4):409-419. DOI: 10.31793/1680-1466.2021.26-4.409.

Адреса для листування: Булдигіна Юлія Валеріївна, yuliya. buldygina@icloud.com; ДУ «Інститут ендокринології та обміну речовин ім. В.П. Комісаренка НАМН України», вул. Вишгородська, 69 Київ 04114, Україна.

Відомості про авторів: Булдигіна Юлія Валеріївна, канд. мед. наук, старш. наук. співроб., провідний науковий співробітник відділу загальної ендокринної патології ДУ «Інститут ендокринології та обміну речовин ім. В.П. Комісаренка НАMH України», ORCID: 00000002-9219-2737; Шляхтич Сергій Леонович, канд. мед. наук, директор Київського центру ендокринної хірургії КНП «Київська міська клінічна лікарня № 3», ORCID: 0000-0002-7784-8320; Терехова Галина Миколаївна, канд. мед. наук, старш. наук. співроб., керівник відділу загальної ендокринної патології ду «Інститут ендокринології та обміну речовин ім. В.П. Комісаренка НAMH України», ORCID: 0000-0002-3195-446X; Федько Тетяна Володимирівна, завідувачка відділення загальної ендокринної патології дУ «Інститут ендокринології та обміну речовин ім. В.П. Комісаренка НАМН України», ORCID: 0000-0002-0541-5200; Клочкова Вікторія Миколаївна, наук. співроб. відділу загальної ендокринної патології ДУ «Інститут ендокринології та обміну речовин ім. В.П. Комісаренка НАМН України», ORCID: 0000-0002-3153-2144; Страфун Леся Сергіївна, наук. співроб. відділу загальної ендокринної патології ДУ «Інститут ендокринології та обміну речовин ім. В.П. Комісаренка НАМН України», ORCID: 0000-0001-9573-0265; Лисова Зоя Григорівна, лікар-ендокринолог відділу загальної ендокринної патології ДУ «ннститут ендокринології та обміну речовин ім. В.П. Комісаренка НАMН України», ORCID: 0000-0003-3049-661Х; Савосько Іван Іванович, лікар-ендокринолог відділу загальної ендокринної патології ДУ «Інститут ендокринології та обміну речовин ім. В.П. Комісаренка HАMH України», ORCID: 0000-0002-0746-4241.

Особистий внесок: Булдигіна Ю.В. - концепція та дизайн дослідження, аналіз результатів, підготовка та написання статті; Шляхтич С.Л. - збір даних літератури, аналіз та інтерпретація; Терехова Г.М. - написання, редагування статті; Федько Т.В. оформлення статті, переклад реферату; Клочкова В.М. - вивчення літератури за темою, аналіз та обробка матеріалу; Страфун Л.С. відбір хворих для аналізу, виконання досліджень; Лисова 3.Г. відбір хворих для аналізу, виконання досліджень; Савосько І.І. відбір хворих для аналізу, виконання досліджень.
Фінансування: стаття підготовлена в рамках бюджетного фінансування Національної академії медичних наук України.

Декларація з етики: автори задекларували відсутність конфлікту інтересів і фінансових зобов'язань.

Стаття: надійшла до редакції 22.11.2021 р.; перероблена 03.12.2021 р.; прийнята до друку 15.12 .2021 р.; надрукована 28.12.2021 p.

For citation: Buldygina YuV, Shlyakhtych SL, Terekhova HM, Fed'koTV, Klochkova VM, Strafun LS, Lysova ZH, Savos'ko II. Personalization of Graves' disease treatment on the basis of clinical and immunological characteristics of the disease. Endokrynologia. 2021;26(4):409-419. DOI: 10.31793/1680-1466.2021.26-4.409.

Correspondence address: Buldygina Yuliya Valeriyivna, yuliya. buldygina@icloud.com; SI «V.P. Komisarenko Institute of Endocrinology and Metabolism of NAMS of Ukraine», Vyshgorodskaya Str., 69, Kyiv 04114, Ukraine.

Information about the authors: Buldygina Yulia Valeriivna, Cand. Sci (Medicine), Senior Research, Leading Researcher of the Department of General Endocrine Pathology, SI «V.P. Komisarenko Institute of Endocrinology and Metabolism of NAMS of Ukraine», ORCID: 0000-0002-9219-2737; Shlyakhtych Serhiy Leonovych, Cand. Sci (Medicine), Director of the Kyiv Center for Endocrine Surgery, Kyiv City Clinical Hospital № 3, ORCID: 0000-0002-7784-8320; Terekhova Halyna Mykolaiivna, Sci (Medicine), Senior Research, Head of the Department of General Endocrine Pathology, SI «V.P. Komisarenko Institute of Endocrinology and Metabolism of NAMS of Ukraine», ORCID: 0000-0002-3195-446X; Fed'ko Tetyana Volodymyrivna, Chief of the Department of General Endocrine Pathology, SI «V.P. Komisarenko Institute of Endocrinology and Metabolism of NAMS of Ukraine», ORCID: 0000-0002-0541-5200; Klochkova Victoria Mykolaiivna, Researcher of the Department of General Endocrine Pathology, SI «V.P. Komisarenko Institute of Endocrinology and Metabolism of NAMS of Ukraine», ORCID: 0000-0002-3153-2144; Strafun Lesya Serhiivna, Researcher of the Department of General Endocrine Pathology, SI «V.P. Komisarenko Institute of Endocrinology and Metabolism of NAMS of Ukraine», ORCID: 0000-0001-95730265, Lysova Zoya Hryhorivna, Endocrinologist of the Department of General Endocrine Pathology, SI «V.P. Komisarenko Institute of Endocrinology and Metabolism of NAMS of Ukraine», ORCID: 00000003-3049-661X, Savos'ko Ivan Ivanovych, Endocrinologist of the Department of General Endocrine Pathology, SI «V.P. Komisarenko Institute of Endocrinology and Metabolism of NAMS of Ukraine», ORCID: 0000-0002-0746-4241.

Personal contribution: Buldygina Yu.V. - concept and design of research, analysis of results, preparation and writing of the article; Shlyakhtych S.L. - literature data collection, analysis and interpretation; Terekhova H.M. - writing, editing the article; Fed'ko T.V. - article design, translation of the abstract; Klochkova V.M. - study of literature on the topic, analysis and processing of material; Strafun L.S. — selection of patients for analysis, research; Lysova Z.H. - selection of patients for analysis, research; Savosko I.I. - selection of patients for analysis, research.

Funding: the article was prepared within the budget funding of the National Academy of Medical Sciences of Ukraine.

Declaration of ethics: the authors declared no conflict of interest and financial obligations.

Article: received 22 November 2021; revised 03 December 2021; accepted 15 December 2021; published 28 December 2021.

Для цитирования: Булдыгина ЮВ, Шляхтич СЛ, Терехова ГН, 
Федько ТВ, Клочкова ВН, Страфун ЛС, Лысова ЗГ, Савосько ИИ. Персонализация лечения болезни Грейвса на основании клинико-иммунологических характеристик течения заболевания. Эндокринология. 2021;26(4):409-419. DOI: 10.31793/16801466.2021.26-4.409.

Адрес для переписки: Булдыгина Юлия Валериевна, yuliya. buldygina@icloud.com; ГУ «Институт эндокринологии и обмена веществ им. В.П. Комиссаренко НАМН Украины», ул. Вышгородская, 69, Киев 04114, Украина.

Сведения об авторах: Булдыгина Юлия Валериевна, канд. мед. наук, старш. науч. сотруд., ведущий научный сотрудник отдела общей эндокринной патологии ГУ «Институт эндокринологии и обмена веществ им. В.П. Комиссаренко HAMH Украины», ORCID: 0000-0002-9219-2737; Шляхтич Сергей Леонович, канд. мед. наук, директор Киевского центра эндокринной хирургии КНП «Киевская городская клиническая больница № 3», ORCID: 00000002-7784-8320; Терехова Галина Николаевна, канд. мед. наук, старш. науч. сотруд., руководитель отдела общей эндокринной патологии ГУ «Институт эндокринологии и обмена веществ им. В.П. Комиссаренко НАMH Украины», ORCID: 0000-0002-3195-446X; Федько Татьяна Владимировна, заведующая отделением общей эндокринной патологии ГУ «Институт эндокринологии и обмена веществ им. В.П. Комиссаренко HAMH Украины», ORCID: 0000-0002-0541-5200; Клочкова Виктория Николаевна, науч. сотруд. отдела общей эндокринной патологии ГУ «Институт эндокринологии и обмена веществ им. В.П. Комиссаренко НАМН Украины», ORCID: 0000-0002-3153-2144; Страфун Леся Сергеевна, науч. сотруд. отдела общей эндокринной патологии ГУ «Институт эндокринологии и обмена веществ им. В.П. Комиссаренко НАМН Украины», ORCID: 0000-0001-9573-0265; Лысова Зоя Григорьевна, врач-эндокринолог отдела общей эндокринной патологии ГУ «Институт эндокринологии и обмена веществ им. В.П. Комиссаренко HAMH Украины», ORCID: 0000-0003-3049-661Х; Савосько Иван Иванович, врач-эндокринолог отдела общей эндокринной патологии ГУ «Институт эндокринологии и обмена веществ им. В.П. Комиссаренко НАMH Украины», ORCID: 0000-0002-0746-4241.

Личный вклад: Булдыгина Ю.В. - концепция и дизайн исследования, анализ результатов, подготовка и написание статьи; Шляхтич С.Л. - сбор данных литературы, анализ и интерпретация; Терехова Г.Н. - написание, редактирование статьи; Федько Т.В. — оформление статьи, перевод реферата; Клочкова В.Н. изучение литературы по теме, анализ и обработка материала; Страфун Л.С. — отбор пациентов для анализа, выполнение исследований; Лысова 3.Г. — отбор пациентов для анализа, выполнение исследований; Савосько И.И. - отбор пациентов для анализа выполнение исследований.

Финансирование: статья подготовлена в рамках бюджетного финансирования Национальной академии медицинских наук Украины.

Декларация по этике: авторы задекларировали отсутствие конфликта интересов и финансовых обязательств.

Статья: поступила в редакцию 22.11.2021 г;; переработана 03.12.2021 г.; принята в печать 15.12.2021 г.; напечатана 28.12.2021 г. 